\title{
An Electrochemical-AFM Study of the Initiation of the Pitting Corrosion of a Martensitic Stainless Steel
}

\author{
Isabelle Reynaud-Laporte, Marylène Vayer, Jean-Pierre Kauffmann \\ and René Erre
}

Centre de Recherche sur la Matière Divisée, CNRS, Université d'Orléans, 1b rue de la Férollerie, 45071 Orléans Cedex 2, France

(Received April 1; accepted September 2, 1997)

$\begin{aligned} & \text { PACS.61.16.Ch }- \text { Scanning probe microscopy: scanning tunneling, atomic force, } \\ & \text { scanning optical, magnetic force, etc. } \\ & \text { PACS.82.45.+z - Electrochemistry and electrophoresis }\end{aligned}$

\begin{abstract}
Pitting corrosion has been studied for more than 5 decades by many different techniques, which have never had the capacity to observe the formation of pits in situ. New techniques such as Atomic Force Microscopy (AFM) or Scanning Tunneling Microscopy (STM) enable the investigations of the evolution of a surface in solution under potential control. The aim of this study was to investigate the mechanism of pitting corrosion of a martensitic stainless steel. Using an AFM able to work in a electrochemical cell, the formation of the corrosion pits was observed in situ. The pitting corrosion was observed to commence on the chromium carbide precipitates and peaks were formed on the surface as an intermediate step.
\end{abstract}

Résumé. - La corrosion par piqûres est étudiée depuis plus de 50 ans mais les différentes techniques employées jusqu'à présent n'ont jamais permis d'observer la formation de piqûres "in situ". De nouvelles techniques comme la microscopie à force atomique et la microscopie à effet tunnel donnent aujourd'hui la possibilité d'étudier, en solution, l'évolution d'une surface sous contrôle de potentiel. Le but de cette étude est de déterminer les mécanismes de la corrosion par piqûres sur les aciers martensitiques. Grâce à un microscope AFM fonctionnant sous cellule électrochimique, la formation de piqûres de corrosion a pu être observée "in situ", mettant ainsi en évidence le rôle joué par les précipités de carbure de chrome dans l'initiation de la piqûre de corrosion.

\section{Introduction}

Pitting corrosion can be stimulated by the addition of chloride ions to acidic or neutral solutions. The presence of inclusions like sulphide [1-3] or oxide inclusions [4] and of carbides precipitates [5] in stainless steel increases the susceptibility of the steel to pit formation. The local distribution and size of the precipitates and the structure of the surface are of vital importance in predicting the corrosion behaviour of stainless steel [1-5]. Many techniques have been used to image the morphology of stainless steel and to investigate the mechanism of pitting corrosion. Techniques such as electron microscopy and optical microscopy examine the surface morphology of stainless steel (inclusions, precipitates, grain boundaries) before and after 
corrosion. Auger Electron Spectroscopy (AES), X-Ray Photoelectron Spectroscopy (XPS) or Energy Dispersion X-ray (EDX) mapping characterize the chemical nature of the surface. All these techniques can only be used for the ex situ examination of the sample during corrosion and can not follow directly, in situ the formation of the pits. Optical microscopy, which can work in situ has a poor spatial resolution $[6,7]$. Techniques such as scanning tunneling microscopy (STM) and atomic force microscopy (AFM) can image the surface topography with extremely high spatial resolution up to atomic resolution in different environmental conditions such as air, controlled atmosphere, ultra high vacuum, in solution and in electrochemical cell. These techniques can follow the evolution of a surface in solution or at an electrode surface during a electrochemical experiment by sequentially imaging the same surface of a sample during its evolution.

In metallurgy, AFM and STM have proved to be very useful tools to study steels [8,9]. Interesting results are now being obtained. The morphologies of phases like martensite or bainite $[10,11]$ or of precipitates [12] have been investigated by air STM. The atomic structures of passive films on austenitic steel [13], on pure iron [14] or on Fe-Cr alloys [15] have been imaged by STM in solution. Corrosion of a $304 \mathrm{~L}$ stainless steel in aqueous chloride media [16] has also been investigated by STM in solution. In situ corrosion studies on metals or alloys $[17,18]$ have been reported but experiments on stainless steel in AFM-electrochemical environment have, to our knowledge, never been reported.

In this paper, we monitored the pitting corrosion of martensitic stainless steel in Steranios solution using an in situ electrochemical AFM. We followed directly a surface during a dynamical application of a potential. This work forms a part of a study of the corrosion of surgical instruments in hospital surroundings and therefore the material observed is martensitic stainless steel used in surgical instrumentation and the Steranios solution is a room temperature disinfectant.

\section{Experimental}

AFM measurements were carried out on a Pico SPM manufactured by Molecular Imaging operating with a Nanoscope E controller from Digital Instrument Corporation. For electrochemical AFM studies, this microscope was combined with a specially one designed by Molecular Imaging electrochemical cell. The same surface of a sample immersed in the electrolyte and submitted to potential control during an electrochemical experiment could be sequentially imaged.

The Molecular Imaging electrochemical cell was composed of a Teflon tube and the sample disk (working electrode). The counter electrode was a platinum wire ( $0.25 \mathrm{~mm}$ diameter) and the reference electrode $\mathrm{Ag} / \mathrm{Ag}_{2} \mathrm{SO}_{4}(+0.625 \mathrm{eV}$ versus a normal hydrogen electrode (NHE)) was in contact with the electrolyte by means of a salt bridge. All potentials placed thereafter were referenced to the $\mathrm{Ag} / \mathrm{Ag}_{2} \mathrm{SO}_{4}$ electrode. The volume of the cell was approximately $700 \mu \mathrm{l}$. The exposed sample area in contact with the solution was approximately $1.2 \mathrm{~cm}^{2}$.

The piezo scanner was capable of a horizontal scanning range of $23 \mu \mathrm{m}$ and a vertical scanning range of $7 \mu \mathrm{m}$. Microfabricated $\mathrm{Si}_{3} \mathrm{~N}_{4}$ gold coated cantilevers, $100 \mu \mathrm{m}$ in length, with integrated $\mathrm{Si}_{3} \mathrm{~N}_{4}$ pyramidal tips were used. The spring constant of the cantilevers was $0.38 \mathrm{~N} / \mathrm{m}$. During surface scanning the tip was always in contact with the surface.

The material observed was a AFNOR Z30C13 (AISI 420) martensitic stainless steel with a chemical composition (w\%) C 0.3 Si 0.35 Mn 0.43 Cr 12.07 S 0.027 P 0.014 Mo 0.02 Co 0.02 Ni 0.34 used for surgical instrumentation. The samples were disks of $14 \mathrm{~mm}$ in diameter and 5 $\mathrm{mm}$ in thickness. They were mechanically wet ground polished with successive $320,500,1200$ grit silicon carbide papers and smoothed with a diamond paste $(1 \mu \mathrm{m})$ to get a mirror finish. 

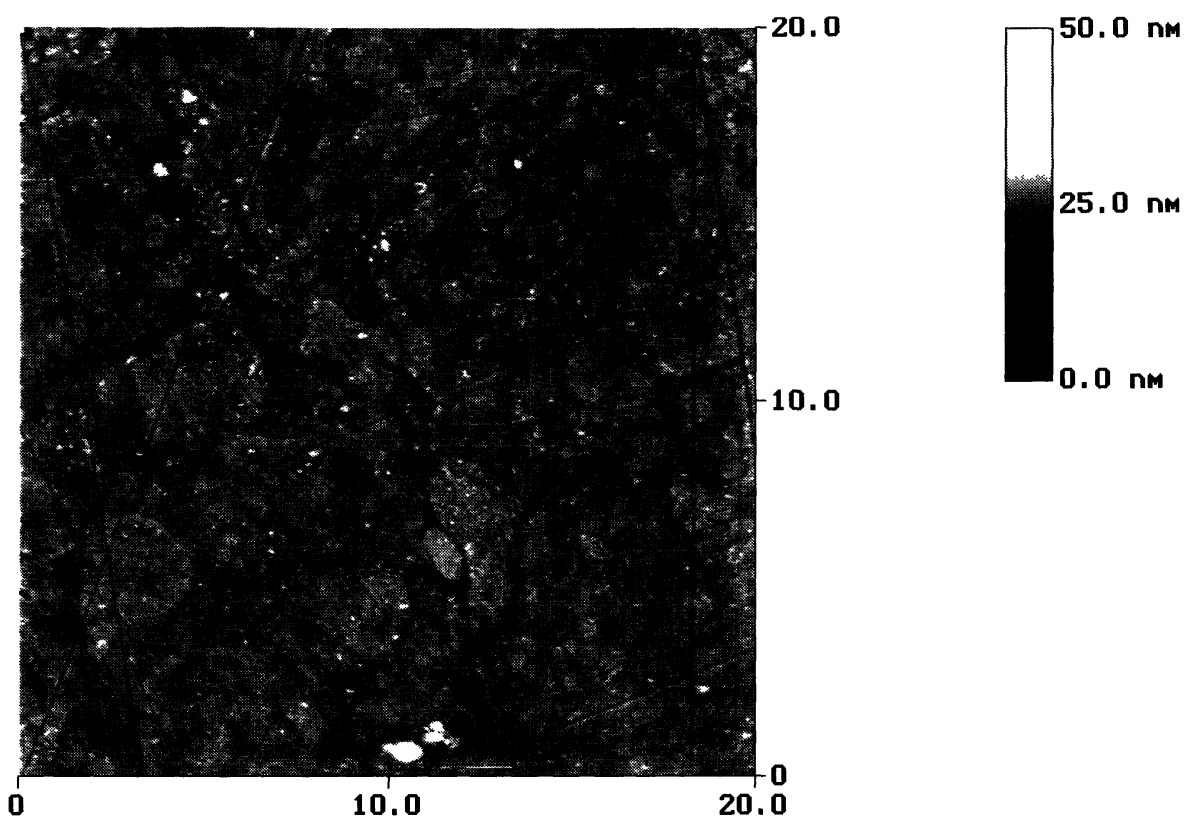

Fig. 1. $-3 \mathrm{D}$ air AFM image of the surface of a Z30C13 martensitic stainless steel polished and etched sample $(20 \mu \mathrm{m} \times 20 \mu \mathrm{m})$.

They were degreased with acetone and ultrasonically cleaned in ethanol.

The electrolyte used was a Steranios solution (Anios Laboratory) at $\mathrm{pH}=6$. This solution contained glutaraldehyde as the active molecule and no chloride. The etching solution was $20 \%$ nitric acid $(d=1.33), 80 \%$ water.

XPS (X-ray Photoelectron Spectroscopy) measurements were performed on a VG ESCALAB MKII equipped with a multidetection analyser controlled by VG eclipse software, a 200W AlK $\alpha$ source and a VG EXO 5 ion gun. The surface of the sample was bombarded with $5 \mathrm{keV}$ argon ions during 90 minutes $\left(p_{\mathrm{Ar}}=6 \times 10^{-8} \mathrm{mbar}, 1 \mu \mathrm{A} / \mathrm{cm}^{2}\right)$ to eliminate the contamination and passive layers. The binding energy scale was calibrated on the 1 s core level of carbon $(\mathrm{C}-\mathrm{H}=284.6 \mathrm{eV})$.

Scanning Electron Microscopy (SEM) and Energy dispersion of X-ray (EDX) mapping were performed on a HITACHI S 4200 combined with a OXFORD Analyser controlled by LINK ISIS software.

\section{Results and discussion}

Two types of samples were examined: polished; polished and etched with the etching solution during 15 minutes. The RMS (Root Mean Square) roughness of the surface of the polished samples was approximately $1 \mathrm{~nm}$.

Both air AFM (Fig. 1) and SEM (Fig. 2a) showed similar images for polished and etched samples where grain boundaries and particles became clearly visible. The size of the grains were between 15 and $30 \mu \mathrm{m}$. Inside the grains particles were round in shape whereas 

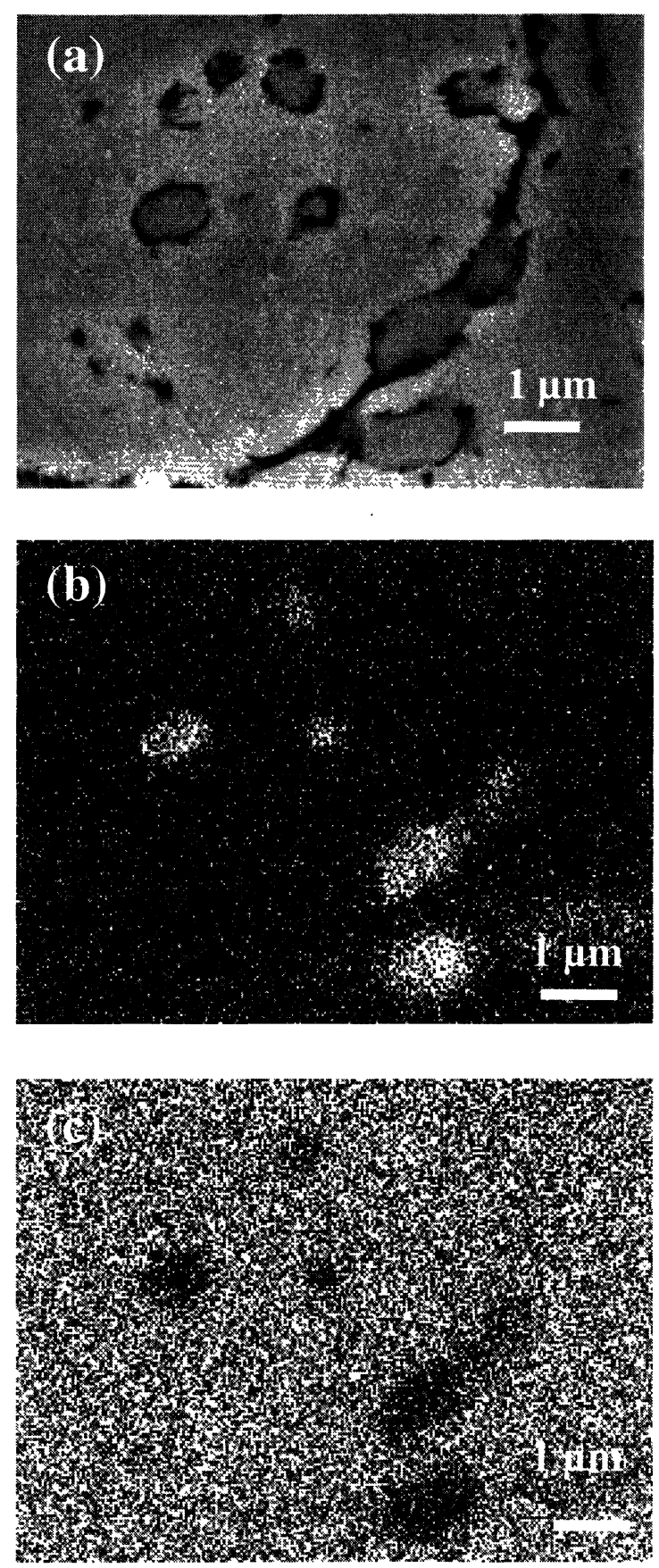

Fig. 2. - Polished and etched sample of Z30C13 martensitic stainless steel a) SEM image; b) EDX mapping of $\mathrm{CrK} \alpha$; c) EDX mapping of $\mathrm{FeK} \alpha$. 


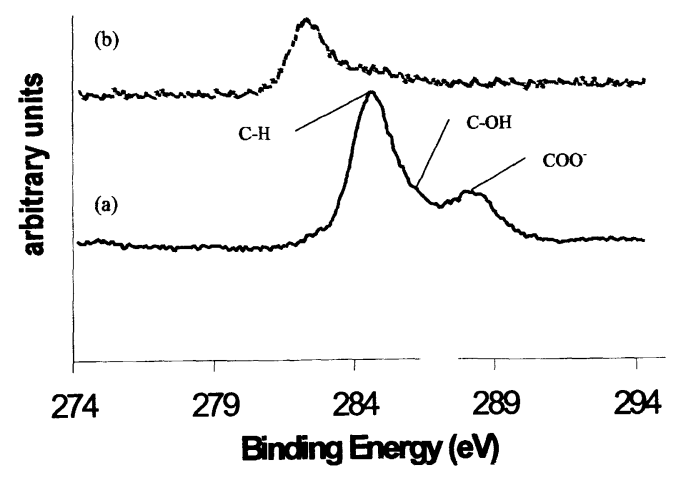

Fig. 3. - C1s spectra polished and etched sample of $\mathrm{Z30C} 13$ martensitic stainless steel: a) before ion bombardment; b) after ion bombardment.

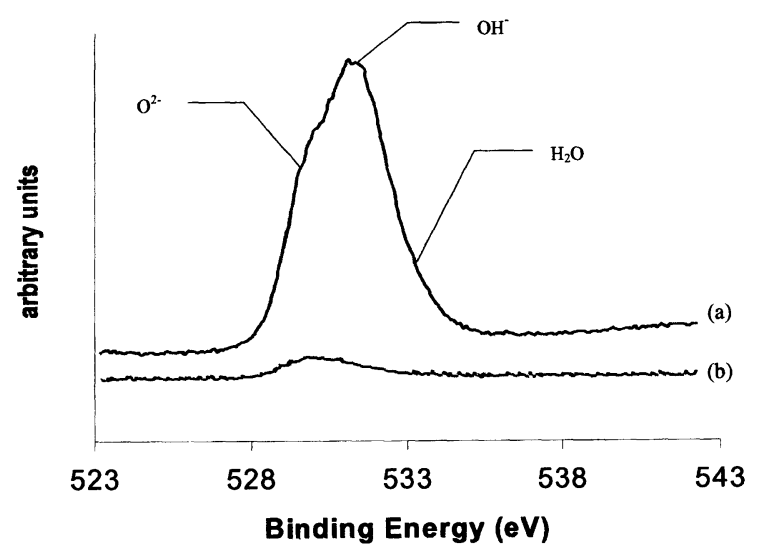

Fig. 4. - O1s spectra polished and etched sample of Z30C13 martensitic stainless steel: a) before ion bombardment; b) after ion bombardment.

in the grain boundaries, particles had more elongated shape. All these particles were of a size of less than $1 \mu \mathrm{m}$.

The EDX analysis of polished and etched samples revealed the presence of chromium, iron and oxygen. With our type of EDX analyser, it was difficult to detect the carbon. Figures $2 \mathrm{~b}$ and 2c present the mappings of $\operatorname{CrK} \alpha, \mathrm{FeK} \alpha$ in parallel with the SEM image (Fig. 2a) and show that the particles on the surface are enriched in chromium. The mapping of OK $\alpha$ is not shown because the $\mathrm{OK} \alpha$ has the equal intensity all over the surface.

XPS spectra were recorded on a polished and etched sample before and after argon ion bombardment. No peaks other chromium, carbon, iron and oxygen were detected. Figure 3 presents the spectra of carbon before (Fig. 3a) and after ion bombardment (Fig. 3b). Figure 4 presents the spectra of oxygen before (Fig. 4a) and after ion bombardment (Fig. 4b). Contamination formed on the surface sample consists mainly of forms of carbons and oxygen. Before argon ion bombardment, three main peaks composed the C1s spectrum, one at $284.6 \mathrm{eV}(\mathrm{C}-\mathrm{H})$, another at $286.3 \mathrm{eV}(\mathrm{C}-\mathrm{OH})$ and another at $288.2 \mathrm{eV}\left(\mathrm{COO}^{-}\right)$. Two main peaks also composed the $\mathrm{O} 1 \mathrm{~s}$ spectrum, one at $529.8 \mathrm{eV}\left(\mathrm{O}^{2-}\right)$ and the other at $531.5 \mathrm{eV}\left(\mathrm{OH}^{-}\right)$and the weak peak at $533.0 \mathrm{eV}$ correspond to $\mathrm{H}_{2} \mathrm{O}$ species. As presented in Figure 3b, the main form of carbon on 

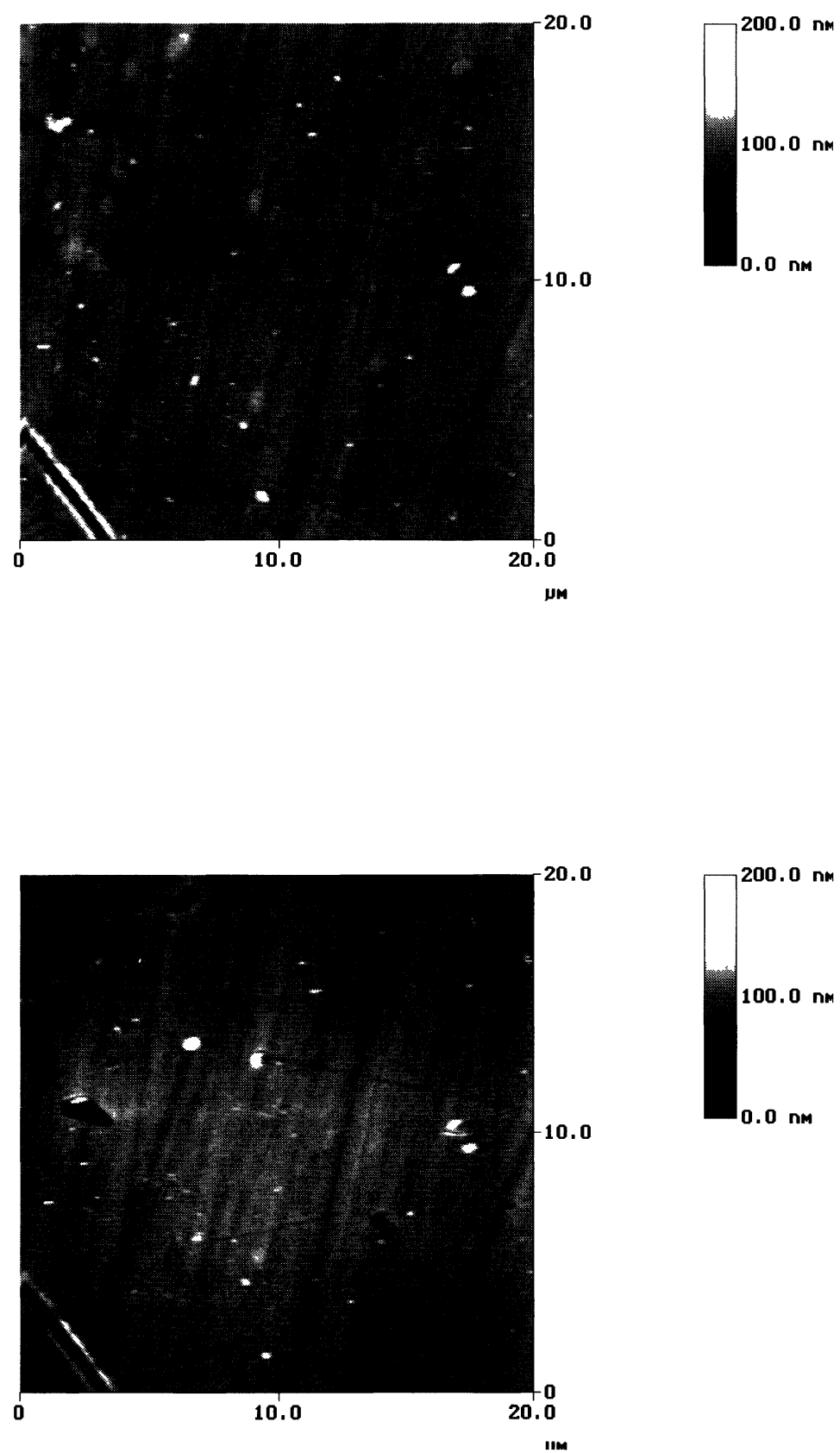

Fig. 5. - Electrochemical AFM images in Steranios solution of a surface of a polished sample of Z30C13 martensitic stainless steel: a) in solution without any applied potential; b) at the end of the electrochemical experiment $E=1.2 \mathrm{~V}$.

the surface after ion bombardment was of a carbide type with a binding energy at $282.3 \mathrm{eV}$. Figure $4 \mathrm{~b}$ indicated that only trace of oxygen in oxide form remained on the surface after ion bombardment. All these attributions are in accordance with the literature [19-22]. 

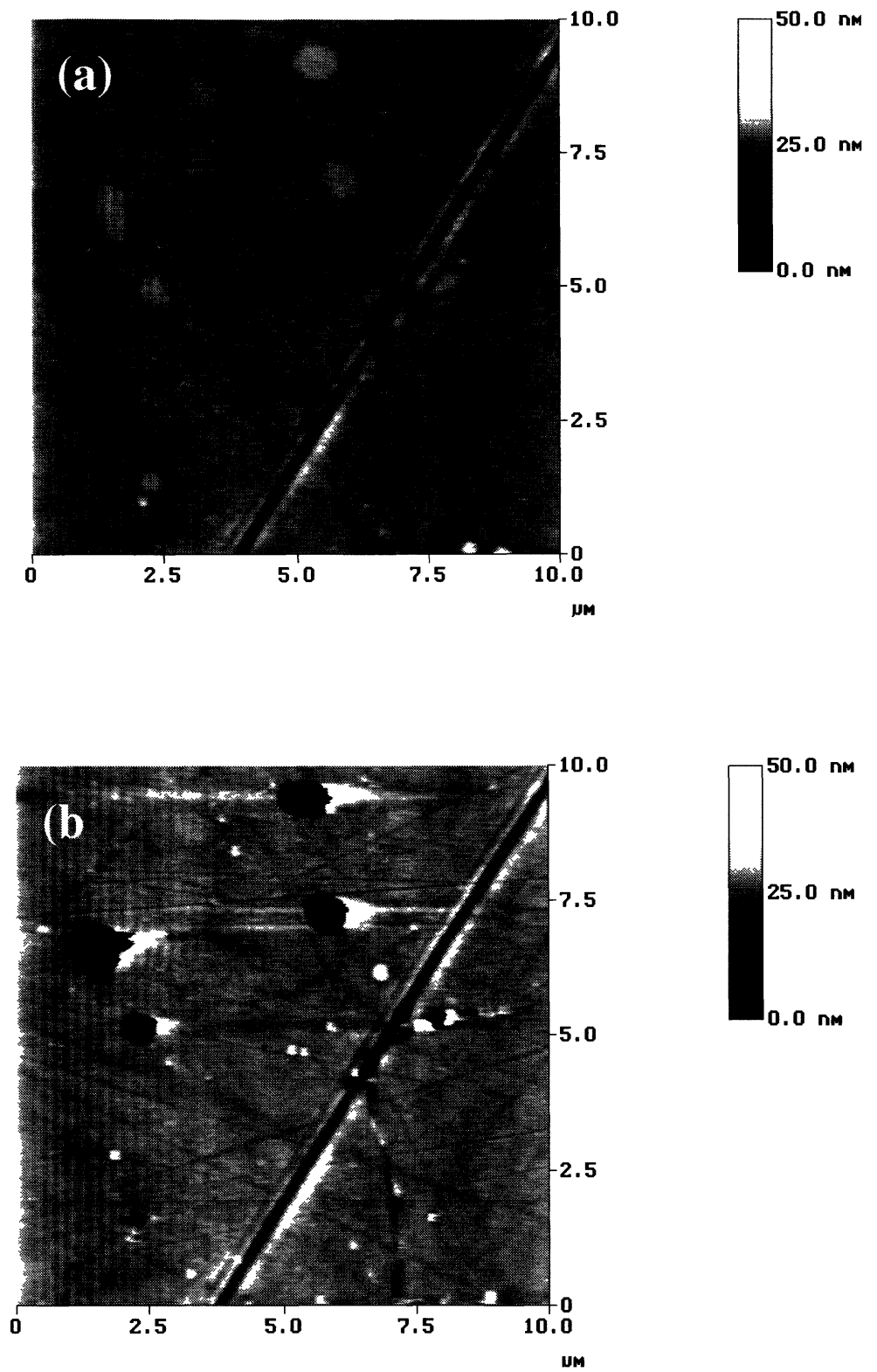

Fig. 6. - Electrochemical AFM images in Steranios solution of a surface of a polished and etched sample of Z30C13 martensitic stainless steel: a) in solution without any applied potential; b) at the end of the electrochemical experiment $E=1.2 \mathrm{~V}$.

Thanks to EDX and XPS analysis, we can conclude that the particles were in fact precipitates of chromium and that carbide is present on the surface. Chromium carbide formed during the heat treatment of the steel has been frequently reported in this type of stainless steel [5]. Our precipitates are undoubtedly chromium carbide. This fact will be demonstrated by Auger mapping in a future publication. 

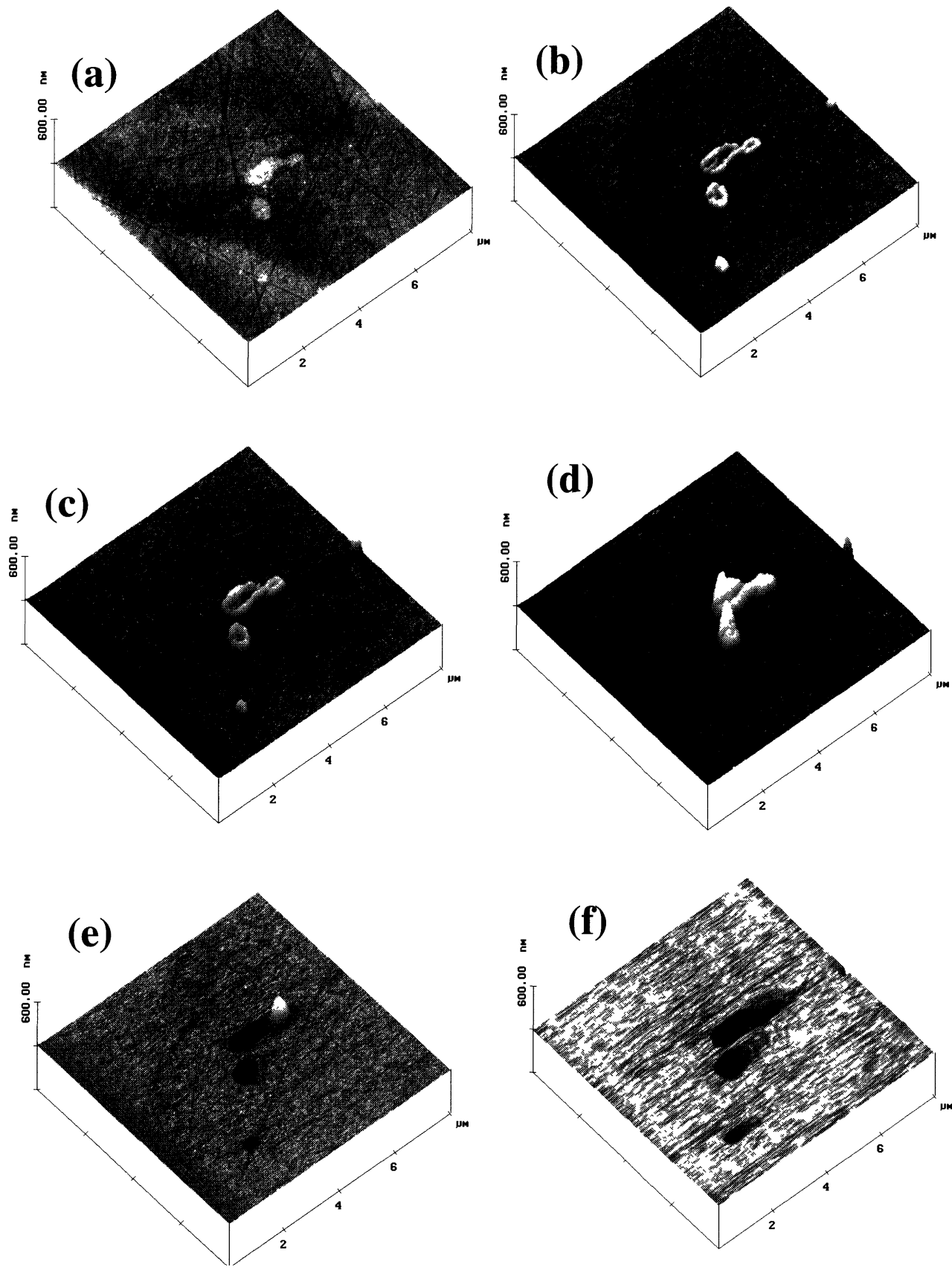

Fig. 7. - Sequential electrochemical AFM images in Steranios solution of a surface of a polished sample of Z30C13 martensitic stainless steel as a function of potential voltage $(E)$ (potential increase rate $=5 \mathrm{mV} / \mathrm{s}$ ): a) $E=$ without any applied potential; b) $E=800 \mathrm{mV} \mathrm{c)} E=800 \mathrm{mV}$ during $150 \mathrm{~s}$; d) $E=800 \mathrm{mV}$ during $250 \mathrm{~s}$; e) $E=950 \mathrm{mV} \mathrm{f}) E=1.2 \mathrm{~V}$. 


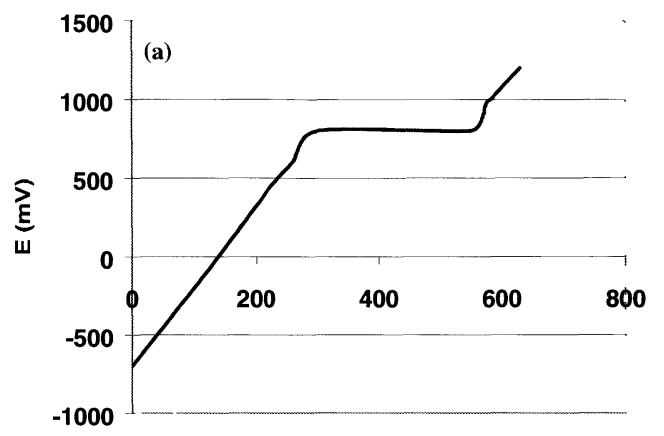

$\mathbf{t}(\mathbf{s})$

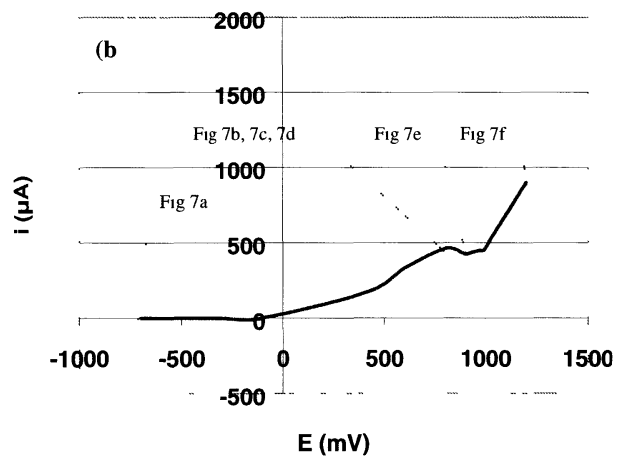

Fig. 8. - a) Temporal evolution of the potential during the electrochemical experiment corresponding to the Figure 7 . b) Voltametric curve $E(V)$. The letters correspond to those used in Figure 7.

Even without etching, as shown in Figure 5a, the polishing already revealed the presence of these precipitates. This was due to the fact that chromium carbide is harder than the martensite phase.

AFM in electrochemical cells was run on the two types of samples: polished samples, and polished and etched samples. Sequential images of the same surface were recorded during the increase of the applied potential. Figures 5 and 6 show the surface of a respectively polished and etched sample before and after the electrochemical experiment. The pitting corrosion was initiated only on the precipitates. After the experiment the precipitates were no longer visible and pits in the shape of these precipitates were observed (Figs. 5b, 6b). However, pit was not observed if no precipitate was present. Within our experimental conditions (Steranios solution without chloride and potential less than $2 \mathrm{~V}$ ), after the disappearance of the precipitates, the corrosion did not propagate. These results indicate that the chromium depleted "matrix" at the matrix-precipitate interface is probably dissolved, then the precipitates could be getting loose.

Figure 7 shows more precisely the evolution of a surface of a polished sample during an electrochemical experiment. An area with a carbide precipitate clearly visible on the surface was chosen (Fig. 7a). The height of these precipitates is between 5 and $10 \mathrm{~nm}$. During the increase of potential from a corrosion potential at $E=-700 \mathrm{mV}$ to $E=1.2 \mathrm{~V}$ the surface was sequentially imaged. Figure $8 \mathrm{a}$ presents the temporal evolution of the potential during the experiment and Figure $8 \mathrm{~b}$ presents the voltamperometric curve relative to Figure $8 \mathrm{a}$. Up to a potential of $E=500 \mathrm{mV}$, nothing visible appeared on the surface with the image remaining 

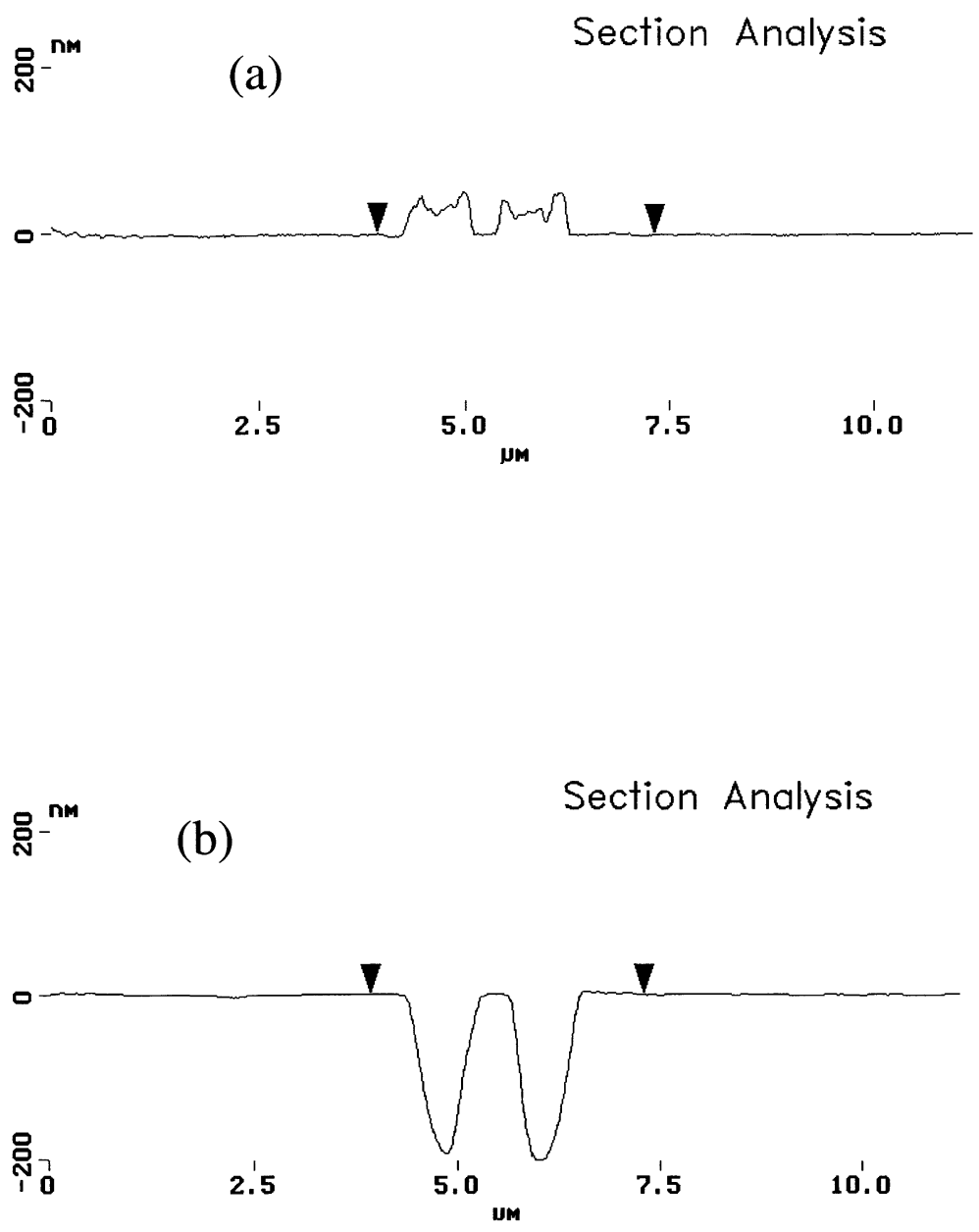

Fig. 9. - Sectional views along a diagonal line in the AFM images: a) $7 \mathrm{~b}$ and b) $7 \mathrm{f}$ of Figure 7, respectively (a) and (b).

the same as that shown in Figure 7a, which was recorded in Steranios solution without any potential. At $650 \mathrm{mV}$, starting from the boundaries of precipitates, a substance seemed to grow out of the precipitates forming peaks. At $800 \mathrm{mV}$, this phenomena was enhanced and the potential was held to follow this phenomenum (Figs. 7b, c, d). The peaks continued to grow in height but their bases were always restricted to the shapes of the precipitates. As the potential was ramped up to $1.2 \mathrm{~V}$ the peaks disappeared, probably by sweeping away by the tip, leaving pits previously hidden by the peaks (Figs. 7e, f). The precipitates were replaced by pits of the same shape.

Figure 9 presents sectional views of the images $7 \mathrm{~b}$ and $7 \mathrm{f}$. During the electrochemical experiment corresponding to Figure 7, the variation of the elongation of the Z-piezo towards the surface is constant in zones without precipitates. So we can conclude that the apparition of these hills is not due to a general erosion of the surface, but to a pitting localized corrosion. 


\section{Conclusion}

These first observations were given a new insight into pitting corrosion and have shown that electrochemical AFM could be a powerful tool used to study these phenomena. The pitting on defects of the surface like precipitates on a surface was well known, but AFM gives direct proof of the initiation of the corrosion of the martensitic stainless steel on the chromium carbide precipitates. This study was also the first evidence for the existence of intermediate steps, like the appearance and disappearance of peaks. Complementary investigations to identify the composition of substance of these peaks are in progress and other stainless steels with others types of defects will be examined.

\section{Acknowledgments}

The authors would like to thank A. Richard for SEM and EDX investigations and R. Benoit for ESCA investigations. This work was supported by the ANIOS laboratory, the LEQUEUX society and the Centre Hospitalier Régional d'Orléans (CHRO).

\section{References}

[1] Stewart J. and Williams D.E., Corros. Sci. 33 (1992) 457.

[2] Ke R. and Alkire R., J. Electrochem. Soc. 139 (1992) 1573.

[3] Baker M.A. and Castle J.E., Corros. Sci. 34 (1993) 667.

[4] Baker M.A. and Castle J.E., Corros. Sci. 33 (1992) 1295.

[5] Lacombe P., Baroux B. and Béranger G., Les aciers inoxydables (Les Éditions de Physique, 1990).

[6] Ahura-Shamba and Roques Y., La Revue de Métallurgie (1994) 1825.

[7] Rodriguez De Schiapparelli E. and Prado Caceres S., J. Materials Sci. 26 (1991) 1454.

[8] Yi Y.S. and Shoji T., J. Nucl. Mater. 231 (1996) 20.

[9] Ogura K., Tsujigo M., Sakurai K. and Yano J., J. Electrochem. Soc. 140 (1993) 1311.

[10] Yang Z., Wang J.J., Fang H.S. and Deng X., J. Mater. Sci. Lett. 14 (1995) 955.

[11] Fang H.S., Wang J.J., Yang Z., Yu H.B., Li Z.G. and Huang G., Prog. Mater. Sci. 4 (1994) 182.

[12] Pischow K.A., Haraldsen A.K. and Korhonen A.S., Mater. Charact 31 (1993) 69.

[13] Olive J.M. and Vignal V., Microsc. Microanal. Microstruct. 5 (1994) 301.

[14] Ryan M.P., Newman R.C. and Thomson G.E., J. Electrochem. Soc. 142 (1995) L177.

[15] Ryan M.P., Newman R.C. and Thomson G.E., J. Electrochem. Soc. 141 (1994) L164.

[16] Fan F.R.F. and Bard A.J., J. Electrochem. Soc. 136 (1989) 166.

[17] Bhardwaj R.C., Gonzalez-Marti and Bockris J.O., J. Electrochem. Soc. 139 (1992) 1050.

[18] Otsuka I. and Iwasaki T., J. Microscopy 152 (1988) 289.

[19] Fierro G., Ingo G.M. and Mancia F., Corrosion 45 (1989) 814.

[20] Olsson C.-O. A. and Hörnström S.E., Corros. Sci. 36 (1994) 141.

[21] Jin S. and Atrens A., Appl. Phys. A42 (1987) 149.

[22] Olsson C.-O. A., Corros. Sci. 37 (1995) 467. 